\title{
PENGARUH KEPERCAYAAN DAN \\ KEPUASAN PELANGGAN TERHADAP LOYALITAS PELANGGAN
}

\author{
Muhammad Bahrudin \\ Siti Zuhro \\ Dosen STIE PGRI Dewantara Jombang
}

\begin{abstract}
This study aimed to examine and explain the effect of variables of customer satisfaction and trust on customer loyalty in the smartphone Samsung Galaxy.It takes 55 users of smartphones who have Samsung Galaxy in Jombang as the research sample.The sampling technique used non-probability, particularly accidental sampling technique. Data are then analyzed by using multiple linear regression analysis. These results indicate that there is a positive and significant impact of customer satisfaction on customer loyalty and trust on customer loyalty.
\end{abstract}

Keywords : Customer Satisfaction, Trust, Customer Loyalty, Smartphone Samsung Galaxy

\section{A. Pendahuluan}

Di era globalisasi dan modern saat ini dengan perkembangan teknologi dan informasi semakin berkembang pesat dari tahun ke tahun tedapat berbagai macam penemuan produk dibidang teknologi informasi dan komunikasi. Salah satu penemuan produk di bidang informasi dan komunikasi adalah smartphone. Smartphone merupakan sejenis handphone yang memiliki kemampuan lebih tinggi dari ponsel biasa (feature phone), dimana smartphone dapat melakukan pengolahan data, browsing, multitasking dan sebagainya sehingga dapat dikategorikan sebagai komputer kecil,. Smartphone atau dalam bahasa indonesia adalah ponsel pintar (telepon seluler) merupakan produk di bidang informasi dan komunikasi yang sangat dicari oleh masyarakat luas, baik itu dari kalangan muda maupun dari kalangan tua untuk menunjang dan meningkatkan produktivitas kerja masyarakat. (Kompasiana.com;2014)

Pada zaman dulu masyarakat berinteraksi dengan satu sama lain menggunakan ponsel (feature phone) untuk menelpon di 
jaringan 2G, SMS (short message service) dan MMS (multimedia messaging service). di zaman moderen ini berinteraksi dengan satu sama lain dibuat lebih mudah dalam membantu masyarakat dalam berinteraksi seperti smartphone sekarang dimana, sekarang sudah ada instant messaging seperti BBM, Whatsaap dll, Video call dengan jaringan 3G, dan Free call dengan jaringan 3G, Email. Dan para produsen aplikasi juga bersaing memberikan kemudahan untuk pengguna smartphone (Inet.detik.com;2009). Menurut lembaga riset global Neilsen bahwa per hari rata-rata orang Indonesia memanfaatkan smartphone selama 189 menit setara 3 jam 15 menit dengan penggunaan dominan untuk sosial media dan multimedia. (Bambani \&Viva.co.id:2013)

Lima besar merek smartphone (Tabel 1) menawarkan teknologi dan fitur canggih smartphone di Indonesia yaitu Samsung, Apple, Lenovo, Huawei, LG dan Xiomi adalah produsen yang bersaing secara ketat mereka berusaha saling merebut pasar. Samsung telah menciptakan kepuasan untuk pelangganya karenasamsung sebagai pemenang dalam kategori smartphone di Indonesian Customer Satisfaction Award, (icsa-indo. com:2014).

Tabel 1

\begin{tabular}{|l|l|l|}
\hline No & Brand & Market share \\
\hline 1 & Samsung & $19,9 \%$ \\
\hline 2 & Apple & $19,7 \%$ \\
\hline 3 & Lenovo & $6,5 \%$ \\
\hline 4 & Huawei & $6,3 \%$ \\
\hline 5 & Xiomi & $4,4 \%$ \\
\hline
\end{tabular}

Sumber : internasional data corporation, 2014 Q4

Setiap industri berusaha bertahan dan bersaing dengan menonjolkan keunggulan dan keunikan di setiap produknya untuk memuaskan kebutuhan konsumen, Peter and Olson (2000 : 157) mengemukakan bahwa jika konsumen tidak dipuaskan, konsumen cenderung beralih merek serta mengajukan keberatan pada produsen, pengecer atau bahkan menceritakannya kepada konsumen lain. Seiring dengan pesatnya perkembangan teknologi informasi dan komunikasi saat ini, maka persaingan di industri ini pun semakin meningkat. Perusahaan dapat 
dikatakan berhasil apabila perusahaan dapat memenuhi kebutuhan dan keinginan konsumen dengan memuaskan atau bahkan melebihi harapan konsumennya. Dalam beberapa tahun terakhir ini kepuasan yang utama dalam suatu organisasi bisnis, hal ini dikarenakan perusahaan menganggap dapat mempengaruhi ingatan pelanggan dan pangsa pasar yang ada (Hansemark dan Albinsson, 2004)

Mowen and Minor (2002) menyatakan Kepuasan konsumen adalah sebagai keseluruhan sikap yang ditunjukan konsumen atas barang atau jasa setelah konsumen memperoleh atau menggunakanya. Oliver kepuasan adalah suatu evaluasi terhadap surprise yang melekat pada suatu pengakuasisian produk dan atau pengalaman mengkonsumsi. Peter and Olson (2000 : 157) menyatakan kepuasan konsumen adalah konsep penting dalam konsep pemasaran dan penelitian konsumen. Sudah menjadi pendapat umum bahwa jika konsumen merasa puas dengan suatu produk atau merek, konsumen cenderung akan terus membeli dan menggunakannya serta memberitahu orang lain tentang pengalaman konsumen yang menyenangkan dengan produk teresebut.

Pengalaman yang mampu membuat sikap positif terhadap konsumen, akan menimbulkan rasa puas atau kepuasan pelanggan, disamping itu untuk perasaan positif yang dibangun terhadap produk akan membangun kepercayaan. Mowen dan Minor (2002: 312) menyatakan kepercayaan konsumen adalah semua pengetahuan yang dimiliki oleh konsumen dan semua kesimpulan yang dibuat konsumen tentang objek, atribut, dan manfaatnya. Kepercayaan merupakan pengetahuan kongnitif kita tentang sebuah objek, maka sikap merupakan tanggapan perasaan atau afektif yang kita miliki tentang objek. Pertamatama konsumen membentuk kepercayaan terhadap sebuah produk kemudian mengembangkan sikap. Jika sikap menjadi positif maka akan terjadi kesetiaan merek.

Peter and Olson(2000 : 162) menyatakan loyalitas merek adalah sebagai keinginan melakukan dan perilaku pembelian ulang. Mowen and Minor (2002:108) menyatakan kesetiaan merek adalah sebagai sejauh mana seseorang pelanggan menunjukan sikap positif terhadap suatu merek, mempunyai komitmen pada merek tertentu, dan berniat untuk membelinya dimasa depan. 
kesetiaan merek dipengaruhi secara langsung oleh kepuasan atau ketidakpuasan dengan merek yang telah diakumulasi dalam jangka waktu tertentu sebagaimana persepsi kualitas produk. Setiadi (2003:129) menyatakan loyalitas merek sebagai sikap menyenangi terhadap suatu merek yang dipresentasikan dalam pembelian yang konsisten terhadap merek itu sepanjang waktu.

Berdasarkan penelitian sebelumnya yang menunjukan kepuasan pelanggan, kepercayaan pelanggan dan harga terhadap loyalitas pelanggan terdapat pengaruh positif, Hal ini menunjukkan bahwa semakin tinggi nilai kepuasan pelanggan, kepercayaan pelanggan dan harga semakin tinggi pula loyalitas pelanggan. (Nina Kurniasari dan Nina Rrmawati, 2012) Oleh karena itu, pentingnya penelitian ini dilakukan karena kepuasan pelanggan, kepercayaan mempunyai pengaruh yang signifikan terhadap loyalitas pelanggan.

Tujuan penelitian ini adalah untuk menguji dan menjelaskan pengaruh kepuasan pelanggan dan kepercayaan merek terhadap loyalitas pelanggan pada produk smartphone Samsung Galaxy.

\section{B. Kajian Pustaka}

\section{Perilaku Konsumen}

Mowen and Minor $(2002 ; 6)$ menyatakan perilaku konsumen (consumer behavior) adalah sebagai studi tentang unit pembelian (buying units) dan proses pertukaran yang melibatkan perolehan, konsumsi, dan pembuanga barang atau jasa, pengalaman, serta ide-ide. Sumarwan (2011:4) mengemukakan bahwa perilaku konsumen diperlihatkan konsumen dalam mencari, membeli, menggunakan, mengevaluasi dan menghabiskan produk dan jasa yang diharapkan dapat memuaskan kebutuhan konsumen.

Proses pembelian dimulai jauh sebelum pembelian sesungguhnya dan berlanjut dalam waktu yang lama setelah pembelian (Kotler dan Amstrong, 1999 : 179), artinya Pemasar harus memberikan perhatian pada keseluruhan proses pembelian dan bukan hanya pada keputusan pembelian.

\section{Loyalitas Pelanggan}

Peter and Olson (2000:162) menyatakan loyalitas merek adalah sebagai keinginan melakukan dan perilaku pembelian 
ulang. Nugroho J. Setiadi (2003:129) menyatakan loyalitas merek adalah sebagai sikap menyenangi terhadap suatu merek yang dipresentasikan dalam pembelian yang konsisten terhadap merek itu sepanjang waktu.

Menurut Mowen and Minor (2002:108) kesetiaan merek (brand loyalty) adalah sebagai sejauh mana seorang pelanggan menunjukan sikap positif terhadap suatu merek, mempunyai komitmen pada merek tertentu, dan berniat terus membelinya di masa depan. Kesetiaan merek dipengaruhi secara langsung oleh kepuasan atau ketidakpuasan dengan merek yang telah diakumulasi dalam jangka waktu tertentu sebagai mana persepsi kualitas produk.

Menurut Nugroho J. Setiadi (2003:129) loyalitas konsumen dapat dikelompokkan ke dalam dua kelompok, yaitu loyalitas merek (brand loyalty) dan loyalitas toko (store loyalty). Loyalitas merek didefinisikan sebagai sikap menyenangi terhadap suatu merek yang direpresentasikan dalam pembelian yang konsisten terhadap merek itu sepanjang waktu. Loyalitas toko ditujukan oleh perilaku konsisten, tetapi dalam store loyalty perilaku konsistenya ialah dalam mengunjungi toko di mana konsumen bisa membeli merek produk yang diinginkan.

Menurut Griffin (2005) loyalitas pelanggan ada beberapa indicator antara lain:

1. Melakukan pembelian berulang secara teratur

2. Mereferensikan kepada orang lain

3. Menunjukan kekebalan terhadap tarikan dari pesaing

\section{Kepuasan Konsumen (Consumer Satisfaction)}

Oliver dalam Peter dan Olson (1996:159) kepuasan adalah suatu evaluasi terhadap surpriseyang melekat pada suatu pengakuasisian produk dan atau pengalaman mengkonsumsi. Peter and Olson (2000:157) menyatakan kepuasan konsumen adalah konsep penting dalam konsep pemasaran dan penelitian konsumen, sudah menjadi pendapat umum bahwa jika konsumen merasa puas dengan suatu produk atau merek, mereka cenderung akan terus membeli dan menggunakannya serta memberitahu orang lain tentang pengalaman mereka yang menyenangkan dengan produk tersebut. Mowen and Minor (2002:89) kepuasan konsumen adalah sebagai keseluruhan 
sikap yang ditunjukan konsumen atas barang atau jasa setelah mereka memperoleh dan menggunakanya. Ini merupakan penilaian evaluative pasca pemilihan yang disebabkan oleh seleksi pembelian khusus dan pengalaman menggunakan atau mengkonsumsi barang atau jasa tersebut.

\section{Kepercayaan Konsumen}

Membangun Kepercayaan sangat penting karena kepercayaan merupakan kunci keberlangsungan hidup merek dalam jangka panjang. Morgan dan Hunt (1994) mengemukakan bahwa kepercayaan adalah variabel kunci dalam mengembangkan keinginan yang tahan lama untuk terus mempertahankan hubungan jangka panjang. Kepercayaan akan membangun persepsi konsumen, apakah merek memiliki integritas, kompetensi dan benevolence dan lainya yang akan mempengaruhi sikap dan perilaku. menurut Mowen and Minor (2002:312) Kepercayaan Konsumen (Cunsumer Beliefs) adalah semua pengetahuan yang dimiliki oleh konsumen dan semua kesimpulan yang dibuat konsumen tentang objek, atribut, dan manfaatnya. Objek (objects) dapat berupa produk, orang, perusahaan, dan segala sesuatu dimana seseorang memiliki kepercayaan dan sikap. Atribut (attributes) adalah karakteristik atau fitur yang mungkin dimiliki atau tidak dimiliki objek. Dua kelas atribut yang luas telah didentifikasikan sebelumnya. Atribut intrinsic adalah segala sesuatu yang berhubungan dengan sifat actual produk. Sedangkan atribut ekstrinsik adalah segala sesuatu yang diperoleh dari aspek eksternal produk, seperti nama merek, kemasan dan label. Manfaat (benefits) adalah hasil positif atribut yang diberikan kepada konsumen.

Didasarkan atas pembelajaran kognitif. Seseorang membentuk tiga jenis kepercayaan yaitu; 1) Kerpercayaan Atribut Objek yaitu pengetahuan tentang sebuah objek memiliki atribut khusus yang disebut kepercayaan atribut objek. Kepercayaan atribut objek menghubungkan sebuah atribut dengan objek, seperti seseorang, barang, atau jasa; 2) Kepercayaan Atribut Manfaat Seseorang dimana Konsumen mencari produk dan jasa yang akan menyelesaikan masalah-masalah mereka dan memenuhi kebutuhan mereka, dengan kata lain memiliki atribut yang memberikan manfaaat yang dapat dikenal;serta 3) Kepercayaan 
yang dibentuk dengan menghubungkan objek dan manfaatnya. Kepercayaan objek dan manfaat merupakan persepsi konsumen tentang seberapa jauh produk, orang atau jasa tertentu yang akan memerikan manfaat tertentu.

\section{Hubungan kepuasan pelanggan dengan loyalitas pelanggan}

Mowen and Minor (2002:89) kepuasan konsumen adalah sebagai keseluruhan sikap yang ditunjukan konsumen atas barang atau jasa setelah mereka memperoleh dan menggunakanya. Ini merupakan pengalaman menggunakan atau mengkonsumsi barang atau jasa tersebut pasca pembelian, konsumen akan mengevaluasi kinerja produk sesuai dengan yang diharapkan atau tidak, mereka akan mengalami emosi positif, negative atau netral, Tanggapan emosional ini bertindak sebagai masukan atau imput dalam persepsi kepuasan/ ketidakpuasan. Mowen and Minor (2002:108) kesetiaan merek dipengarui secara langsung oleh kepuasan atau ketidakpuasan dengan merek yang telah diakumulasi dalam jangka waktu tertentu sebagai mana sebagai mana persepsi kualitas produk.

\section{Hubungan kepercayaan dengan loyalitas pelanggan}

Mowen and Minor (2002:322) Kepercayaan adalah semua pengetahuan yang dimiliki oleh konsumen dan semua kesimpulan yang dibuat konsumen tentang objek, atribut dan manfaatnya. Mengingat kepercayaan merupakan pengetahuan kongnitif kita tentang sebuah objek, maka sikap merupakan tanggapan perasaan atau afektif yang kita miliki tantang objek. Pertama-tama konsumen membentuk kepercayaan terhadap sebuah produk kemudian mengembangkan sikap terhadapnya dan akhirnya membelinya atau pertama-tama konsumen melakukan perilaku pembelian produk dan kemudian membentuk kepercayaan serta sikap terhadap produk tersebut. Dengan fungsi pengetahuan, sikap seseorang membentuk sebuah kerangka kerja referensi dimana mereka menginterpretasikan dunianya. Oleh karenanya, sikap konsumen sangat mempengaruhi bagaimana mereka secara selektif mengekspos dirinya dan mengamati komunikasi pemasaran. Fungsi pengetahuan juga membantu menjelaskan beberapa pengaruh kesetiaan merek. Dengan mempertahankan sikap 
positif terhadap produk, konsumen dapat menyederhanakan hidup mereka. Kesetiaan merek dapat mengurangi waktu pencarian yang diperlukan untuk memperoleh sebuah produk dalam memenuhi kebutuhanya.

\section{Kerangka Konseptual}

Berdasarkan landasan teori dan penelitian sebelumnya dibangun kerangka konseptual penelitian sebagai berikut:

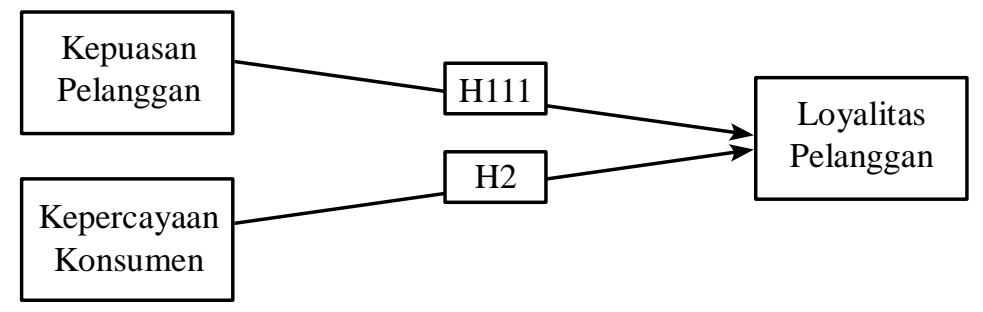

Gambar 1

Kerangka konseptual

Sumber : Teori dan Penelitian Sebelumnya

\section{Hipotesis}

Berdasarkan kerangka pemikiran yang disintesakan dari landasan teori dan penelitian sebelumnya, hipotesis-hipotesis yang diajukan dalam penelitian ini adalah sebagai berikut:

H1: Kepuasan pelanggan berpengaruh terhadap loyalitas pelanggan

H2: Kepercayaan berpengaruh terhadap loyalitas pelanggan

\section{Metodologi Penelitian}

Penelitian ini merupakan penelitian kausal yang mejelaskan hubungan antara variabel Kepuasan Pelanggan (X1); Kepercayaan (X2) terhadap variabel (Y) Loyalitas Pelanggan.

Populasi dalam penelitian pengguna smartphone Galaxy Samsung. Populasi dalam penelitian adalah pengguna smartphoneh Galaxy Samsung dengan kisaran harga 1,5 Juta - 2 Juta; sudah menggunakan smartphone selama 1 tahun, dan usia antara 15-30 tahun. Penentuan jumlah minimal sampel dihitung 
berdasarkan rumus : $\mathrm{n}=(5 \times$ jumlah indikator yang digunakan $)$ Sugiono (2008). Yaitu sebagai berikut $: \mathrm{n}=(5 \times 11$ indikator $)$ adalah 55 responden.

Pengambilan sampel penelitian menggunakanteknik sampling insidental. Peneliti menyebarkan angket kepada pengguna smartphone Galaxy. Teknik analisis data yang digunakan adalah regresi linear berganda.

\section{Variabel dan Definisi Operasional Variabel}

Dalam penelitian ini menggunakan dua variabel independen yaitu Kepuasan Pelanggan (X1) dan Kepercayaan Merek (X2) dan satu variabel independen Loyalitas Pelanggan $(Y)$.

\section{Definisi Operasional Variabel}

\section{Kepuasan Pelanggan (X1)}

Kepuasan Konsumen dalam penelitian ini adalah persepsi tentang keseluruhan sikap yang ditunjukkan konsumen terhadap merek Samsung setelah menggunakannya. Berdasarkan (Peter and Olson, 2000 : 157) dikembangkan indikator kepuasan pelanggan sebagai berikut:

1) Perasaan senang menggunakan produk Samsung

2) Cederung terus membeli

3) Memberitahu orang lain tentang pengalaman menyenangkan dengan produk tersebut

\section{Kepercayaan (X2)}

Kepercayaan merek dalam penelitian ini adalah hasil evaluasi keseluruhan konsumen berdasarkan pengalaman menggunakan smartphone Samsung, sehingga menimbulkan sikap tertentu, yang di ikuti dengan tumbunya tingkat kepercayaan. Yang diukur dengan menggunakan indikator dari Mowen and Minor (2002: 312) sebagai berikut:

a. Kepercayaan terhadap atribut objek

Kepercayaan terhadap atribut objek adalah sikap percaya yang dihasilkan dari evaluasi terhadap atribut objek:

1) Memori internal besar

2) Sensor kamera 5 megapixel sampai 8 megapixel

b. Kepercayaan terhadap manfaaat atribut

Kepercayaan terhadap manfaat atribut adalah sikap percaya yang ditimbulkan terhadap manfaat atribut: 
1) Kapasitas untuk menginstal beragam aplikasi

2) Hasil jepretan kamera dan video jernih

c. Kepercayaan terhadap manfaat produk

Kepercayaan terhadap manfaat adalah sikap percaya terhadap manfaat produk secara umum dibandingkan dengan memakai feature phone (ponsel java) adalah

1) Dapat melakukan multitasking atau perpindahan beberapa aplikasi sekaligus

\section{Loyalitas Pelanggan (Y)}

Loyalitas pelanggan dalam penelitian ini adalah sebagai sejauh mana seorang pengguna menunjukan sikap positif terhadap suatu merek, mempunyai komitmen pada merek tertentu, dan berniat terus membelinya di masa depan yang diukur dengan indikator dari Griffin $(2005,31)$ sebagai berikut:

1) Melakukan pembelian berulang

2) Mereferensikan kepada orang lain

3) Menunjukan kekebalan terhadap tarikan dari pesaing

\section{Uji Validitas}

Sebelum dilakukan penyebaran angket, dilakukan pengujian validitas instrumen penelitian kepada 30 responden. Uji validitas menggunakan kriteria yang dikemukakan oleh Sugiono ( $2014: 178$ ), aitem dinyatakan valid jika $r \geq 0,03$.

Tabel 2

Uji Validitas

\begin{tabular}{|l|l|l|l|l|}
\hline Variabel & Data & $\begin{array}{l}\text { Pearson } \\
\text { Correlation }\end{array}$ & $\begin{array}{l}\text { Sig. } \\
(2-\text {-tailed })\end{array}$ & Validitas \\
\hline X1 & $\mathrm{X} 1$ & 0.707 & 0.000 & Valid \\
\cline { 2 - 5 } & $\mathrm{X} 2$ & 0.841 & 0.000 & Valid \\
\cline { 2 - 5 } & $\mathrm{X} 3$ & 0.821 & 0.000 & Valid \\
\hline $\mathrm{X} 2$ & $\mathrm{X} 1$ & 0.413 & 0.023 & Valid \\
\cline { 2 - 5 } & $\mathrm{X} 2$ & 0.702 & 0.000 & Valid \\
\cline { 2 - 5 } & $\mathrm{X} 3$ & 0.734 & 0.000 & Valid \\
\cline { 2 - 5 } & $\mathrm{X} 4$ & 0.763 & 0.000 & Valid \\
\cline { 2 - 5 } & $\mathrm{X} 5$ & 0.583 & 0.001 & Valid \\
\hline
\end{tabular}


Pengaruh Kepercayaan dan Kepuasan Pelanggan terhadap ...

\begin{tabular}{|l|l|l|l|l|}
\hline \multirow{3}{*}{$\mathrm{Y}$} & $\mathrm{X} 1$ & 0.755 & 0.000 & Valid \\
\cline { 2 - 5 } & $\mathrm{X} 2$ & 0.797 & 0.000 & Valid \\
\cline { 2 - 5 } & $\mathrm{X} 3$ & 0.815 & 0.000 & Valid \\
\hline
\end{tabular}

Sumber : Data primer diolah, SPSS 16.0

Sedangkan untuk hasil uji reliabilitas digunakan kriteria antara 0,61 - 0,80dinyatakan memiliki reliabilitas tinggi (Arikunto, 2011 : 101), hasil dideskripsikan pada Tabel 3 Berikut :

Tabel 3

Uji Reliabilitas

\begin{tabular}{|l|l|l|l|}
\hline No & Variabel & Alpha & keterangan \\
\hline 1 & $\mathrm{X} 1$ & 0.701 & Reliabel \\
\hline 2 & $\mathrm{X} 2$ & 0.648 & Reliabel \\
\hline 3 & $\mathrm{Y}$ & 0.636 & Reliabel \\
\hline
\end{tabular}

Sumber: Data primer diolah, SPSS 16.0

D. Hasil Dan Pembahasan

Karakteristik Responden

Tabel 4

Karakteristik Responden

\begin{tabular}{|c|c|c|l|c|l|}
\hline Usia & Frek. & Persentase & $\begin{array}{c}\text { Jenis } \\
\text { Pekerjaan }\end{array}$ & Frek. & Persentase \\
\hline 15-20 tahun 32 & $58 \%$ & Pelajar & 18 & $33 \%$ \\
\hline$>20-25$ tahun 17 & $31 \%$ & Mahasiswa & 24 & $44 \%$ \\
\hline$>25-30$ tahun 6 & $11 \%$ & $\begin{array}{l}\text { Pekerja / } \\
\text { Karyawan }\end{array}$ & $23 \%$ \\
\hline
\end{tabular}

Sumber : Data Primer diolah tahun 2015

Berdasarkan Tabel 4, menunjukkan bahwa sebagian besar pengguna martphone Samsung galaxy berusia antara 15-20 tahun sebesar 58\%, berasal dari pelajar diikuti kisaran usia > 20-25 tahun sebesar 31\% berasal dari Mahasiswa sesuai dengan target pasar yang tertuju pada pengguna usia muda, dan pada usia tersebut aktivitas bersosialisasi dan berkomunikasi cenderung tinggi. 


\section{Uji Analisis Regresi Linear Bergada}

Dalam pengolahan data dengan menggunakan regresi linier, dilakukan beberapa tahapan untuk mencari hubungan antara variabel independen dan variabel dependen. Pada Tabel 5 disajikan hasil uji analisis regresi linier berganda.

Tabel 5

Hasil Pengujian Analisis Regresi Linear Berganda

\begin{tabular}{|c|l|l|l|c|c|}
\hline \multirow{2}{*}{ Model } & \multicolumn{2}{|c|}{$\begin{array}{c}\text { Unstandardized } \\
\text { Coefficients }\end{array}$} & $\begin{array}{l}\text { Standardized } \\
\text { Coefficients }\end{array}$ & \multirow{2}{*}{$\mathrm{T}$} & Sig. \\
\cline { 2 - 4 } & $\mathrm{B}$ & Std. Error & Beta & & \\
\hline $\begin{array}{c}1 \\
\text { (Constant) }\end{array}$ & 1.495 & 1.688 & & .886 & .380 \\
\hline $\mathrm{X} 1$ & .437 & .092 & .504 & 4.768 & .000 \\
\hline $\mathrm{X} 2$ & .257 & .080 & .339 & 3.205 & .002 \\
\hline
\end{tabular}

a. Dependent Variable : Y Sumber

:Data Primer diolah, SPSS 16.0

Berdasarkan hasil analisis regresi dengan menggunakan output computer diatas maka dapat dilihat persamaan regresinya adalah $\mathrm{Y}=1.495+0.437+0.257+\mathrm{e}$. Persamaan garis regresi yang positif antara varibel kepuasan pelanggan (X1) dan kepercayaan (X2) terhadap variabel loyalitas pelanggan (Y) karena nilai Beta pada Unstandardized Coefficients sebesar 0.437 atau dengan persentase $43,7 \%$ pengaruh terhadap kepuasan pelanggan dan sebesar 0.257 atau dengan persentase 25,7\% untuk kepercayan. Dengan demikian semakin tinggi kepuasan pelanggan dan kepercayaan maka loyalitas pelanggan semakin tinggi. Besarnya pengaruh kepuasan pelanggan dan kepercayaan terhadap loyalitas pelanggan dapat dilihat pada Tabel 6. 
Pengaruh Kepercayaan dan Kepuasan Pelanggan terhadap ...

Tabel 6

Model Summary ${ }^{\mathrm{b}}$

\begin{tabular}{|c|c|c|c|c|}
\hline Model & $\mathrm{R}$ & $\mathrm{R}$ square & $\begin{array}{c}\text { Adjusted R } \\
\text { Square }\end{array}$ & $\begin{array}{c}\text { Std. Error } \\
\text { of the } \\
\text { Estimate } \\
1\end{array}$ \\
.679 & .461 & .441 & 1.21468 \\
\hline
\end{tabular}

Predictors : (Constant), X2, X1

a. Dependent Variable : $Y$

Sumber : Data Primer diolah, SPSS 16

Berdasarkan Tabel 6, dapat dijelaskan bahwa diperoleh nilai $\mathrm{R}$ Square sebesar 0.461, kontribusi pengaruh variabel kepuasan pelanggan dan kepercayaan terhadap loyalitas pelanggan sebesar $46,1 \%$

Hasil Uji Hipotesis

Tabel 7

Hasil pengujian Uji T

\begin{tabular}{|c|ll|l|l|l|l|l|}
\hline Model & $\begin{array}{l}\text { Unstan- } \\
\text { dardized } \\
\text { Coefficients }\end{array}$ & $\begin{array}{l}\text { Standar- } \\
\text { dized } \\
\text { Coefficients }\end{array}$ & $\mathrm{T}$ & Sig. & \multicolumn{2}{|l|}{$\begin{array}{l}\text { Collinearity } \\
\text { Statistics }\end{array}$} \\
\hline & $\mathrm{B}$ & $\begin{array}{l}\text { Std. } \\
\text { Error }\end{array}$ & Beta & & & $\begin{array}{l}\text { Tole- } \\
\text { rance }\end{array}$ & VIF \\
\hline 1 (Constant) & 1.495 & 1.688 & & .886 & .380 & & \\
\hline X1 & .437 & .092 & .504 & 4.768 & .000 & .927 & 1.079 \\
\hline X2 & .257 & .080 & .339 & 3.205 & .002 & .927 & 1.079 \\
\hline
\end{tabular}

a. Dependent Variable: Y

Coefficients $^{\mathrm{a}}$

Sumber Data Primer diolah, SPSS 16.0

Berdasarkan Tabel 7 dapat diketahui nilai P-value $\mathrm{t}$ statistic untuk variabel kepuasan pelanggan 0.000 dan kepercayaan 0.002 terhadap loyalitas pelanggan, memiliki nilai lebih kecil dari 0.05 , sehingga dapat simpulkan bahwa $\mathrm{H}_{1}$ dan $\mathrm{H}_{2}$ dapat diterima, artinya kepuasan pelanggan dan kepercayaan signifikan mempengarui loyalitas pelanggan. Dengan demikian dapat diartikan bahwa $\mathrm{H} 1$ dan $\mathrm{H} 2$ dapat diterima.

\section{Pembahasan}

Berdasarkan hasil deskripsi variabel kepuasan pelanggan

BISNIS, Vol. 3, No. 1, Juni 2015 
menunjukkan bahwa secara umum kepuasan pelanggan tinggi, namun ada salah satu item yang harus diperhatikan yang dibawah rata rata item cenderung terus membeli, yang harus diperbaiki kembali karena masih di bawah rata-rata. Sedangkan variabel kepercayaan secara umum tinggi. Pada variabel kerpercayaan terdapat beberapa yang berada di bawah rerata yaitu item kapasitas untuk menginstal beragam aplikasi dan hasil jepretan kamera dan video jernih, yang harus lebih diperhatikan oleh perusahaan. Sedangkan variabel loyalitas pelanggan secara umum menunjukan tinggi. Dan ada salah satu diantara item variabel loyalitas pelanggan yang dibawah rerata yaitu item menunjukan kekebalan terhadap tarikan pesaing. Dengan demikian dapat disimpulkan bahwa semakin besar kapasitas memori internal untuk menginstal aplikasi yang lebih banyak dan memberikan hasil kamera yang lebih jernih pada smartphone Samsung galaxy, maka semakin tinggi pula loyalitas pelanggan ke smartphone samsumg galaxy karena konsumen sudah merasa puas dan percaya pada smartphone Samsung galaxy dan konsumen juga akan menunjukkan kekebalan terhadap tarikan smartphone dari pesaing.

Berdasarkan hasil pengujian hipotesis terbukti bahwa Kepuasan Pelanggan, Kepercayaan berpengaruh sigmifikan positif terhadap Loyalitas Pelanggan pada Pengguna smartphone Samsung Galaxy, artinya bahwa Kepuasan Pelanggan yang tinggi maka akan meningkatkan Loyalitas Pelanggan, dan Kepercayaan yang kuat terhadap merek Galaxy Samsung akan diikuti oleh meningkatnya Loyalitas Pelanggan.

Hasil pengujian tersebut membuktikan teori dari Mowen and Minor (2002) bahwa kesetiaan merek dipengarui secara langsung oleh kepuasan atau ketidakpuasan dengan merek yang telah diakumulasi dalam jangka waktu tertentu. Hasil penelitian ini mendukung penelitian sebelumnya yang dilakukan oleh Erik Siswoyo (2009) bahwa kualitas pelayanan, kepercayaan dan kepuasan pelanggan berpengaruh signifikan terhadap loyalitas nasaba. Dan penelitian yang dilakukan oleh Nina Kurniasari dan Nina Ernawati (2012) bahwa kepuasan pelanggan, kepercayaan dan harga berpengaruh signifikan terhadap loyalitas pelanggan. 


\section{Simpulan}

Berdasarkan hasil pembahasan dapat disimpulkan bahwa untuk membangun loyalitas pelanggan tinggi diperlukan kepuasan pelanggan dan kepercayaan yang tinggi dari pelanggan. Namun ada beberapa variabel yang harus diperhatikan untuk variabel kepuasan pelanggan item cenderung terus membeli, variabel kepercayaan item kapasitas untuk menginstal beragam aplikasi dan item hasil jepretan kamera dan video jernih, dan variabel loyalitas pelanggan item menunjukan kekebalan terhadap tarikan dari pesaing memiliki nilai yang dibawah rerata yang harus diperhatikan oleh perusahaan.

\section{E. Saran}

Berdasarkan hasil penelitian dan kesimpulan, maka saran dalam penelitian ini dapat dikemukakan sebagai berikut:

1. Karena variabel kepuasan pelanggan item cenderung terus membeli (X2), variabel kepercayaan item kapasitas untuk menginstal beragam aplikasi (X3) dan hasil jepretan kamera dan video jernih (X4) dan variabel loyalitas pelanggan item menunjukan kekebalan terhadap tarikan dari pesaing (Y3) mempunyai nilai dibawah rerata. Jadi agar konsumen puas menggunakan produk smartphone Samsung Galaxy, sebaiknya Samsung mobile memberikan nilai tambah seperti kamera yang lebih jernih seperti xiomi atau fitur kamera yang lebih beragam dan memberikan memori internal yang lebih besar agar dapat menginstal beragam aplikasi yang terdapat di play store, agar konsumen tidak bosan karena setiap produk memiliki PLC (product life cycle) apalagi sekarang pesaingan dunia smartphone semakin ketat para produsen bersaing dan menawarkan teknologi dan fitur canggih dari sebuah smartphone untuk merebut pasar dan konsumen merek pesaing, seperti para pesaing memberikan nilai tambah seperti contoh Xiomi yang memberikan harga lebih murah, Sony memberikan ponsel anti air, LG memberikan laser autofocus, desain melengkung dan fitur knock code.

2. Sedangkan saran untuk penelitian selanjutnya disarankan untuk menambah variabel lain, misalnya variabel harga, kualitas,dan lain lain. Karena variabel kepuasan pelanggan dan kepercayaan mempengaruhi sebesar $46,1 \%$ sisanya $53,9 \%$ dipengaruhi oleh variabel lain. 


\section{DAFTAR PUSTAKA}

Arikunto, Suharsimi. 2011, Prosedur Penelitian - Suatu Pendekatan Praktik. Penerbit/Publisher: Rhineka Cipta

Ghozali, Imam. 2005. Aplikasi Analisis Multivariate dengan Program SPSS edisi 3. Semarang: BP UNDIP

Griffin Jill, 2005, Customer Loyalty Menumbukan dan Mempertahankan Kesetiaan Pelanggan, Jakarta: Erlangga

Hansemark, Ove C. and Marie Albinsson. 2004, Customer Satisfaction and Retention: the experience of individual employess. Managing Service Quality Journal

ICSA, http://www.icsa-do.com/winner/icsa_2014.html, diakses 20 April 2015

Internasional Data Corporation., https://www.idc.com, diakses 20 April 2015

Kurniasari, Nina. dan Ernawati, Nina., 2012, Pengaruh Kepuasan Pelanggan, Kepercayaan, Dan Harga Terhadap Loyalitas Pelanggan Laundry Kencling Semarang, Vol. No. 3, Mei 2012

Kotler, Philip dan Armstrong, Gary.1999, Prinsip-Prinsip Pemasaran Edisi 12, Penerbit : Erlangga. 2011, Perilaku Konsumen Teori dan Penerapannya dalam Pemasaran, Penerbit: Ghalia Indonesia.

Mowen,J.C., dan Minor, M., 2001,Perilaku Konsumen,edisi 5, Jakarta: PT Penerbit Erlangga

Mowen. J. C., dan Minor, M., 2002, Perilaku Konsumen, Jilid 1 , Jakarta: PT Penerbit Erlangga 
Pengaruh Kepercayaan dan Kepuasan Pelanggan terhadap ...

Mudrajad, Kuncoro, 2004, Metode Kuantitatif Teori dan Aplikasi Untuk Bisnis dan Ekonomi, Edisi Kedua, UPP APP YKPN, Yogyakarta.

Peter, J.P., dan Olson, J.C., 2000, Perilaku Konsumen dan Strategi Pemasaran, Jakarta: Erlangga

Riset Global Neilsen., http://teknologi.news.viva.co.id/ news/read/433547-hasil-survei-kebiasaan-penggunasmartphone-di-indonesia, diakses tanggal 15 Mei 2015

Setiadi, N.J., 2003, Perilaku Konsumen, Jakarta: Kencana Prenada Media Grup

Siswoyo, Erik, 2009,Analisis Pengaruh Kualitas Pelanggan, Kepercayaan Dan Kepuasan Nasabah Terhadap Loyalitas Nasabah Pada PT Bank Jateng Pemuda Semarang

Sujadna, 2005, Metode Statistika, Bandung:Tarsito

Sugiyono, 2007, Metode Penelitian Kuantitatif dan R\&D, Bandung: CV. Alfabeta

Vendor Aplikasi Memanjakan Penggunanya, http://www. detik.com/inet/read/2009/02/24/102753/1089538/317/ diakses 15 Mei 2015. 
